\title{
Explaining the Quiddity of Prophet Khidr (PBUH) with the Focus on Interpretive Analysis of Verses 60 to 82 of Surah Al-Kahf and Removing Doubts About It
}

\author{
Zohreh Narimani ${ }^{1}$; Jafar Firoozmandi Bandpey ${ }^{2}$; Zahra Javadi Nasr ${ }^{2}$ \\ ${ }^{1}$ Assistant Professor of University of Sciences and Teachings of the Holy Qur'an, Faculty of Qur'anic Sciences, \\ Kermanshah Branch, Iran (Corresponding Author) \\ ${ }^{2}$ Assistant Professor, Department of Arabic Language and Literature, Kermanshah Branch, Islamic Azad \\ University, Kermanshah, Iran \\ ${ }^{3}$ MA Graduated from University of Sciences and Teachings of the Holy Qur'an, Iran
}

Email: zohrehnarimani92@yahoo.com; j.firoozmandi@gmail.com; javadinasr@yahoo.com

http://dx.doi.org/10.18415/ijmmu.v8i10.2922

\begin{abstract}
The story of the meeting of Prophet Moses with Prophet Khidr is mentioned in verses 60 to 82 of Surah al-Kahf. The latter is introduced as Khidr in the narrations and in the following years he also met with the Imams, on the basis of which his long life has been discussed. This story has many ambiguities and doubts. How the Prophet Moses, as the 'Ulu al-'Azm Prophet, followed that person and the deeds done by the wise person, which is not accepted in any divine law, and this has left much discussions for the commentators. The cause of this endless life is not well known. Most commentators have gone into the confusing details of the story and tried to resolve it. They have considered Moses' obedience to Khidr outside the legislative system and due to the evolution of Khidr's actions, they have considered a different personality for him that has no similar texts anywhere and attributed the long life of this personality to drinking the Fountain of Youth. These questionable justifications led to the study of the essence of the problem and the identification of the nature of Khidr's personality from different angles. According to the interpretation of the Qur'an by the Qur'an, we have examined the various dimensions of the story in order to gain a Qur'anic knowledge of this character. At first glance, this story does not have the same in other verses, but in many similarities in the identity, duties and deeds of Khidr with the angels, the possibility has been stronger that Khidr has been an angel. Introducing Prophet Khidr not as a human being but as an angel including the divine messenger angels can answer all questions and doubts accurately and without any conflict and opposition with the Qur'an and religious principles and Shiism.
\end{abstract}

Keywords: Khidr (PBUH); Moses (PBUH); Angel; Man; the Interpretation of the Qur'an by the Qur'an

\section{Introduction}

An important part of the Qur'an is devoted to the lives of the Prophets. Contrary to the Torah, the Qur'an does not mention the details and names of various people and characters in the stories. One of 
these stories in which the Qur'an only deals with the essence of the story and does not mention the names of the people in the story, and it just mentions the names of the story according to the narrations, is the story of the meeting of Prophet Moses (PBUH) and Khidr (PBUH) in the verses 60 to 82 of Surah alKahf. The story begins with the journey of Moses (PBUH) with a young man for a personal visit. The sign of the meeting place is the jump of their fish into the sea. The Qur'an does not explicitly mention the resurrection of fish. Some commentators believe that the fish was apparently dead and even cooked, and after the sea water of the meeting place, i.e. the Fountain of Youth (Suyūṭ̂, 231/4), was poured on it, it was revived and jumped into the sea ${ }^{1}$. The meeting takes place and Moses (PBUH) asks Khidr (PBUH) to teach him what he has been taught so that he also can grow. According to the narrations, this story is related to the end of the life of Moses (PBUH), that is, at the time of prophecy and after passing the tests and excuses of the Israelites! (Abu al-Futūh al-Razī, 4/13) Musa (PBUH) makes Khidr (PBUH) accompany him. Khidr (PBUH) asks him not to ask questions. Finally, this Prophet promises pure obedience to a person who was apparently a Prophet according to the opinions of the commentators (Tayyeb, 8/379; TTabrasī, 7/642; Makarem Shirazi, 12/482; Sadeghi Tehrani, 18/141, 4/230; Fakhreddin Razī, 21/480). At the beginning of the companionship, there is no news about the young companion of Moses (PBUH) who was the companion of Moses (PBUH) at the beginning. Moses and his new companion, Khidr, board the ship. Khidr (PBUH) pierces the ship. With the objection of Moses (PBUH), Khidr (PBUH) reminds him that he has already told him that he cannot be patient. Moses (PBUH) asks not to be reprimanded for forgetfulness. They are traveling until Khidr (PBUH) kills a teenager. Again, Moses (PBUH) protests whether you are killing an innocent soul? Khidr (PBUH) reminds the covenant again. This time, Moses (PBUH) promises not to accompany him again if he asks any question again. They arrive in a city and the residents refuse to give them food. Khidr (PBUH) begins to repair a wall that is collapsing. Once again, Moses (PBUH) protested that he wished he were paid. And this is the time of separation and Khidr (PBUH) or the companion of Moses (PBUH) interprets the events; Khidr (PBUH) drilled the ship so that the usurping king would not take it from its owners; he committed the murder of a teenager so as not to mislead his parents and repaired the wall to preserve the treasure beneath it that was for orphan children. Moses (PBUH) accepts the interpretations expressed by Khidr (PBUH) and does not ask again why he does not tell the owners of the ship the story of the usurping king? Or by what law can an immature and indebted teenager be killed for fear of misleading his parents in the future?! And why not leave the treasure to a trustworthy person so that it does not fall into the hands of the incompetent if the wall is destroyed again? What is the matter and who is Khidr (PBUH)?

\section{Research Background}

The general interpretations and books of the stories of the Prophets about the story of Khidr (PBUH) and Moses (PBUH) and the doubts about it can be considered as the background of this research. In these writings, while describing the story in detail, they have mostly tried to remove doubts by assuming that Khidr (PBUH) is a human being and a Prophet; while his being a Prophet has a lot of doubt, and in this case, all the arguments to dispel the doubts of the story are shaky. From this point of view and with this approach, no independent article or book has been published so far. Therefore, in this research, we intend to study the nature of Moses' companion (PBUH) with the method of library research and using the method of interpreting the Qur'an to the Qur'an, and then to resolve doubts about this.

\section{The story of Khidr (PBUH) and Moses (PBUH) in the Testaments}

The story is not mentioned in the Torah or the Bible, but there is a similar story in some books by 11th-century Jewish scholars. The story is related to Elias and Joshua ibn Levi and is mentioned in the

\footnotetext{
${ }^{1}$ Ibn Abbas, Ibn Zayd, and Mujāhid: God has revived the fish. Ubay ibn Ka'b: God returns the soul of the fish. (Tūsī, 7 / 66
} 
commentary books of the third century (Talmud) and is different from the story of Khidr (PBUH) and Moses (PBUH). (Najafi Khomeini, 10/386; Makarem Shirazi, 12 / 510) But the question here arises how the companions and others became aware of this story and asked the Prophet (PBUH) about it? (Feyz Kashani, 3/248).

\section{Companion of Moses (PBUH) in the Qur'an and Hadiths}

In the Holy Qur'an, the guide and companion, or in a better interpretation, the teacher of Moses (PBUH) is mentioned as a servant: "Then found they one of Our slaves, unto whom We had given mercy from Us, and had taught him knowledge from Our presence." (Kahf: 65) ${ }^{2}$ In the narrations, he has been also introduced as Khidr. His name was Balya ibn Malkan, and Khidr was his title; Muqātil ibn Sulaymān considers him the son of 'Amyayil from the Israelite. (Balkhī, 2/592) This scholar is known as Khidr among commentators and narrators by citing the first hadith. (Najafi Khomeini, 10/385; Makarem Shirazi, 12/509) The content of the hadith is as follows: Imam Șādiq (AS) said, "Indeed, Khidr was a messenger. God, the Blessed and Exalted, sent him to his people to invite them to monotheism and to acknowledge the Prophecy of the Prophets, messengers and his divine Books, and his miracle was that he did not sit on any dry wood unless it became green and did not sit on any grassless ground unless it grew green, and that is why he was called Khidr. His name was Taliya ibn Malkan Ibn 'Abir Ibn Arfakhshad ibn Sam Ibn Noah (PBUH). Indeed, when God spoke to Moses and revealed the Torah to him, and wrote for him a sermon and a description of everything in the tablets, and put his miracle in Bright Hand and his staff and the storm and the locusts and the mites and frogs and blood and the splitting of the sea and the drowning of Pharaoh and his armies and He did what was necessary for the perfection of humanity in him. He said to himself: I do not see that God Almighty has created a people more knowledgeable than me. So God Almighty revealed to Gabriel (PBUH): O Gabriel, find my servant Moses before he is perished and tell him: Indeed, he is a devout man in the Majma al-Bahrain. Follow him and learn from him. So Gabriel (PBUH) was revealed to Moses (PBUH) because of what God Almighty had commanded him. So Moses (PBUH) knew the cause. (Ibn Babiwayh, Causes of Sharia, 2/59) ${ }^{3}$.

\section{4-1. Time of Meeting of Moses (PBUH) and his Companion}

The name of Moses (PBUH) has been mentioned 129 times in the Qur'an and according to the commentators, his story has been also mentioned in verses 60 to 82 of Surah al-Kahf. Because if another person was considered, a reference would be made according to the style of the Qur'an. The timing of the meeting is questionable. If the story is related to before the mission of Moses (PBUH), the suspicion of being taught to him may be resolved by another person, but the deeds of Khidr (PBUH) are still highly questionable. Many commentators (Feyz Kashani, 3/251; Bahrānī, 3/645; Arūsī Ḥuwayzī, 3/276) based on the hadith of Imam Șādiq (AS) believe that the meeting took place after the mission of Moses (PBUH) and even at the end of his life. In this case, how can a 'Ulu al- 'Azm Prophet be trained by a Prophet with a lower rank, even after passing all the divine tests? How is it that the 'Ulu al-'Azm Prophet is often forced to apologize another Prophet by his repeated threats of leaving accompany?

\section{Questions and Doubts About the Story}

If, according to the interpretations, we consider the companion of Prophet Moses to be Prophet Khidr or the devout man, then in the interpretation and understanding of the verse, we will face many unsolvable questions and doubts. These issues are as follows:

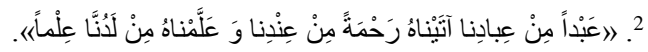

${ }^{3}$ Some of the commentators, who have used the concept of this hadith include: Bahrānī, 1416, and 645. Tayyeb, 8/ 378, Balkhī , ;593 / 2 ,1423Tafsīr Ayyashi, 2 / 330; 332; Qomi, 37/ 2 
1. The first question that came before was how the 'Ulu al-'Azm Prophet would be educated and threatened and warned by a Prophet with a lower rank?

2. Why did not Khidr (PBUH) inform the owners of the ship that the usurping king was looking for them in order to save their property in some way - by changing the route?

3. Why does Khidr (PBUH) encroach on the property of others without permission?

In response, Najafi Khomeini says that piercing the ship in exchange for preserving the ship's collection was to repel corruption and the possibility of satisfaction of ship owners was predictable if the cause was known (Najafi Khomeini, 10/381). But in that case, one might ask, can the property of others be damaged just by the possibility of future consent? If repelling corruption has been meant, why does Moses, as God's chosen Prophet, not understand this? Some believe that from the point of view of the evolutionary system, there is nothing wrong with God causing man to be in a small problem in order to save him from a bigger problem (Makarem Shirazi, 12/508). Another question arises here: Is the companion of Moses, as a Prophet or a devout person, allowed to enter and occupy the system of evolution in this way? And basically, if Khidr (PBUH) was sure of the satisfaction of the ship owners, why did he not inform them to make their own decision? Another question is what happens to the other crew of the ship by drilling it? And why they, like Moses, were not exposed to Khidr and do not warn against piercing a ship?

4. How does Moses (PBUH) notice the murder of a young man or an immature child (Tūsī, 7/75; Tabataba'i, 3/345) but others are not aware of the incident and do not look for the killer? Why does Moses (PBUH) not prevent the murder and only protests in the end? Basically, Moses could prevent the murder and he did nothing, and he was content with just asking? The commentators have not paid attention to these cases.

5. How does Khidr (PBUH) kill a young man for the sake of his future? According to Țabrasī, whenever a person makes corruption, God is free to eliminate him. (Tabrasī, 6/753) Some, such as Tayyeb and Najafi Khomeini, believe that the young man was an apostate (Tayyeb, 8/390; Najafi Khomeini, 10/381) and on the other hand, it is possible that the criminal laws of the past religions are different from the holy religion of Islam. Secondly, all the deeds of Khidr (PBUH) were by the command of God Almighty. (Al-Kahf: 82) Thirdly: The infidelity of the young man was definite so that he does not believe in the future (Najafi Khomeini, 10/377). Makarem Shirazi also believes that from the point of view of the developmental system, there is nothing wrong with God causing an immature child to be caught in an accident, because his existence carries great dangers in the future. (Makarem Shirazi, 12/508) Tabrisì's view on God's will is correct, but here the murder is against the divine laws and their speech is not the answer to our question. In response to the young man's apostasy, it should be said that the words of Khidr (PBUH) are the possibility of misleading the parents in the future ${ }^{4}$, and the interpretation of the difference in criminal law is wrong according to the objection of Moses (PBUH). As for doing God's command, the contradiction created for Moses (PBUH) cannot be resolved; what he was commissioned to do is the opposite of what was done by Khidr (PBUH), and despite the narration of the story, Moses $(\mathrm{PBUH})$ is still in charge of the same matter ${ }^{5}$, and neither Moses nor anyone else can do it just because of the possibility of error in the future, and retaliated the infidel and criminal against a possible infidelity and crime. The certainty of young's infidelity in the future does not solve anything, because according to the Shari'a laws, a person who has not committed a crime does not deserve punishment, and this is a divine law.

6. Why does Khidr not warn young's parents about his future and leave the choice to them? Tabrasī believes that God was all-knowing that the faith of his parents is possible only by killing this

${ }^{5}$ Qiṣāṣ: Ishah 21, book of Exodus; verse 45, surah Mā’idah.

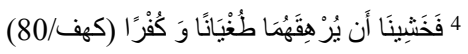


child (Ṭabrasī, 6/753). So why other Prophets have not used this method to preserve the rule and religion of God and its continuation? For example, why were Amir al-Mu'minin (PBUH), who knew what Ibn Muljam would do in the future, not exposed to him!? This statement is also in conflict with verses such as verse 107 of Surah Al-An'am, which indicates that there is no compulsion to guide people.

7. How does Khidr (PBUH) repair the wall so that Moses (PBUH) does not notice the treasure under the wall? The principle is to rebuild the wall from the ground up. (Tayyeb, 8/388) Some commentators cite this narration: Khidr $(\mathrm{PBUH})$ put his hand on the wall and said: Stand up, by the permission of God Almighty. (Qomi, 2/38).

8. If Khidr (PBUH) built the wall in an unusual way and with the help of God, why did Moses (PBUH) expect him to ask the people of the city for food in return?

9. Why does not Khidr (PBUH) give the possibility of re-destroying the wall and leaving the treasure to a trustworthy person? How can he be sure that the orphans will find the treasure?! In some narrations, there are seven intermediaries between the orphans and their righteous father (Tabrasī, 6/754) and in some, seven hundred years. The commentators do not answer this question and the strange way of preserving the property of the orphans intensifies the abnormality of the characteristics of Khidr (PBUH).

10. Why Moses (PBUH) asks Khidr (PBUH) for permission to obey him? Why does the 'Ulu al'Azm Prophet want to follow the non-'Ulu al-'Azm Prophet? Tayyeb says that obedience was not considered in religious affairs and was meant to accompany. (Tayyeb, 8/382) Sheikh Tūsī believes that obedience was meant in the path, teachings, commands and prohibitions. (Tayyeb, 8/382) If the purpose was to accompany, Moses (PBUH) should have prevented the actions of Khidr (PBUH) and not even apologize for his objection. (Tabataba'i, 1345/13) Moses (PBUH) says "I will not disobey you in anything." (Fooladvand, 301 (Al-Kahf: 69)) This means pure obedience to Moses (PBUH). If according to Tūsī, obedience to the commands is considered, other problems will occur. In verse 144 of Surah AlA'rāf, we read: "He said: O Moses! I have preferred thee above mankind by My messages and by My speaking (unto thee)" 6

God has chosen Moses for the prophecy and guidance of all other contemporary people, if Khidr is one of the people, so he must follow Moses (PBUH) and not vice versa.

11. How can a human being - even if Prophet Khidr (PBUH) - with a lower rank become the teacher of the 'Ulu al- 'Azm Prophet? The commentators (Tūsī, 7/70; Najafi Khomeini, 10/388) believe that Khidr (PBUH) is teaching Moses (PBUH) and the deeds done by him are contrary to what was taught to Moses (PBUH). Allameh Majlisī (RA) says: The Prophet should not need others in laws and rulings; but there is no problem in learning other sciences from another human being as he learns from the angels. (Majlisī, the history of Prophets, 1/759) But according to the following verse which is addressed in absolute way, it is emphasized that in no matter should the Prophet be surpassed, and the Prophets in every age are ahead of all contemporaries in performing their duties - especially social duties: "O ye who believe! Be not forward in the presence of Allah and His messenger" (Hujurāt: 1) ${ }^{7}$

The examples of the Qur'an also confirm this issue, when several Prophets are present in one era, we see obedience to the 'Ulu al-'Azm Prophet; the obedience of Aaron (PBUH) to Moses (PBUH) (A'rāf: 142; Ṭa Hā: 30) and Lūt (PBUH) to Abraham (PBUH) (Ankabūt: 26) are among these cases. Angels are not introduced as teachers of the Prophets in the Qur'an, so that we can justify the teaching and intimidation of Prophet Khidr to the 'Ulu al-'Azm Prophet by quoting their teachings, but angels are merely obedient bearers of divine teachings (Takwir: 21). The main discussion is about the teaching of the Prophet of God, which in many cases is done by the angels and there is no reason for their higher

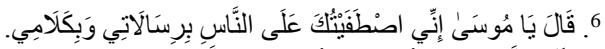

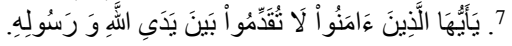


position, but it is related to the duties and communication of God's trust to the Prophets. In fact, angels are merely mediators of education and are the true teachers of God. This statement is confirmed by the first and second verses of Surah Al-Rahmān, which introduce God as the teacher of the Qur'an to the Prophet: "The Beneficent, Hath made known the Qur'an" (Al-Rahmān: 1-2) ${ }^{8}$

In addition, according to a hadith from Imam Șādiq (AS), Prophet Moses was more knowledgeable than Prophet Khidr. (See: Kulaynī, Muhammad ibn Ya'qub, Al-Kāfī, vol. 1, p. 261.)

12. According to the hadith of Imam Șādiq (AS) - mentioned earlier - how can one accept the 'Ulu al-'Azm Prophet be arrogant? How is this a Prophet whose way of thinking is the cause of his destruction? In some interpretations, the theme is quoted as follows: Someone asked Moses (PBUH): "Has God created someone more knowledgeable than you?", and he replied: "I do not know", then Gabriel will guide him to Majma al-Bahrain. (Tayyeb, 8/378) But in fact both modes of narration refer to the arrogance of Moses (PBUH) (God forbid). While verse 51 of Surah Maryam says about Moses' purification for God: "And make mention in the Scripture of Moses. Lo! he was chosen, and he was a messenger (of Allah), a prophet"9 and that Satan cannot tempt the sincere servants of God (Al-Hijr: 40; p: 83), it does not seem to be correct to know the reason for this meeting to humiliate Moses (PBUH) (Tayyeb, 8/377), because on the one hand, there is the issue of obedience, and on the other hand, the honor of this Prophet is free from this accusation, even in the last years of his life and after enduring all the sufferings, problems and excuses of Israelites and achieving the position of talking to God. In the verses of Surah al-Kahf, there is no trace of the arrogance of Moses (PBUH), but his humility and obedience is the highlight of the meeting.

13. What was the real reason for the meeting? Acquisition of knowledge or punishment? Shaykh al-Tūsī has narrated from Ubayy ibn Ka'b: God wanted to make Moses (PBUH) aware that He had given Khidr (PBUH) a knowledge that is not with Moses (PBUH). (Al-Tūsī, 7/66) the hadith has mentioned the verse 145 of Surah A'râf: "And We wrote for him, upon the tablets, the lesson to be drawn from all things and the explanation of all things, then (bade him)" 10

The view of commentators is different about the phrase "of all things". Allameh believes that there was a selection of everything in the tablets. (Tabataba'i, 2/845) According to Sadeghi Tehrani, what the people of Torah needed was written in tablets. (Sadeghi Tehrani, 11/301) The author of Majma ${ }^{\circ}$ alBayān says that everything necessary for religion was in the tablets (Ṭabrasī, 4/734) and this seems more correct, because if we consider the reason for the failure of the Torah to be the change of the needs of time or distortion, this is not true for the time of Moses (PBUH). In this case, the Torah could not be an invitation to the public. The commentators consider "an explanation for all things" to mean the expression of rules and laws. (Tabataba'i, 8/245; Sadeghi Tehrani, 11/301; Țabrasī, 4/734) According to these points, the reason for the visit cannot be considered as gaining worldly knowledge, because what was needed was given to Moses (PBUH), and in practice, the sciences that Khidr (PBUH) taught him were not worldly sciences or even sciences, based on which the Law of Moses establishes.

The issue of punishment and discipline of a Prophet is not discussed after leading a people, because there is no special punishment that requires returning from a mistake. Rather, it seems that Moses (PBUH) is aware of the affairs and interpretation of the events of the universe. That is, the same growth that he seeks at the beginning of his meeting with Khidr. And in confirmation of speech, we suffice the expression of Khidr in the interpretation of actions and the request of Moses in teaching growth.

14. Moses (PBUH) could not even wait to see these things and was not able to do them. (Tabataba'i, 1345/13) So what did this companionship and journey add to the understanding and character

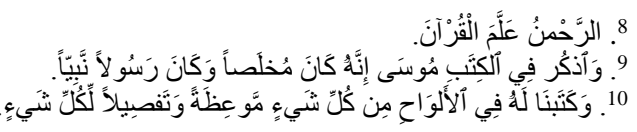


of Moses (PBUH)? Some commentators regarding the following verse believe that Khidr doesn't want to prove Moses is absolutely impatient but he means Moses cannot wait on his deeds due to not knowing the interior of Khidr's actions. (Țabrasī, 6/747) Some also believe that Moses (PBUH) could never wait to accompany Khidr (PBUH). There are four points in the verses: The coming of Lan for eternal deny in being able to wait, and then the unknown form (Nakarah) of the word patience, which has a general meaning. Khidr (PBUH) also says that you cannot be patient and considers the reason as lack of knowledge about the cause of patience. (Tabataba'i, 13/342) These four points show that Moses (PBUH) gained something other than patience in this companionship. (Tayyeb, 8/385) The commentators' discussion about the possibility or non-existence of patience is not the main issue but shows the structural difference between the two characters and is not clarified by these explanations.

15. What is the justification for the long life of Khidr (PBUH)? Khidr (PBUH) was present in the time of Moses (PBUH) and some narrations refer to his presence in the presence of the Imams (AS). (Qomi, 2/45) In some narrations, people ask how the last Imam has lived so long, to answer this doubt the longevity of Prophet Khidr (PBUH) is given as an example. (Karajaki, 2/115) Some have also resorted to the narrations of the Fountain of Youth. (Ayyashi, 2/115) Abu Ali Jaba'i believes that Khidr may not be allowed to live so far, because if he was alive, people would know him and be informed of his place. (TTabrasī, 6/754) Țabrasī replied that it is possible for God to keep him alive, especially since - By consensus of Muslims and non-Muslims - The actions of the Prophets are usually contrary to custom. There is also no obstacle for him to be among the people and for them to see and not know him (Țabrasī, 6/754). But in fact, the Qur'an speaks against the words of TTabrasi and it is believed that usually the deeds of the Prophets are not contrary to habit and they are like other human beings who are only revealed to them (Kahf: 110) and also the long life of Khidr (PBUH) needs to be argued. There is no mention of his life in the Qur'an, but at the same time it explicitly mentions the long life of Noah (PBUH) who lived among the people all the time: "And verily we sent Noah (as Our messenger) unto his folk, and he continued with them for a thousand years save fifty years"11

So why it is not argued in those narrations about the longevity of Noah? On the other hand, according to verse 34 of Surah Al-Anbiyā' informs that no human being before the Holy Prophet (PBUH) had any eternal life and the narrations that attributed the longevity of Khidr (PBUH) to the Fountain of Youth is more similar to Jewish storytelling and is contrary to the Qur'an in which there is no mention of the Fountain of Youth and it has been mentioned only in the words of some commentators and storytellers. (Tabataba'i, 13/338) Regarding his absence or not being known, it should be said that so what is the use of his being alive for the people? Is the only justification for the presence of Khidr (PBUH) at different times because of his longevity?

\section{4-2. Nubuwwat of Khidr}

There is a lot of talk about the character of Khidr (PBUH) among scholars and the common people. According to Allameh, these stories and anecdotes are not devoid of pre-Islamic myths and fake and false information. (Tabataba'i, 1339/13) There is a lot of difference about him being a Prophet. Jaba'̄ considers him a Prophet because it is not permissible for a Prophet to follow a non-Prophet. (Tūsī, 7/70) Al-Romani said that it is not permissible for Moses to be taught by Khidr unless Khidr is a Prophet because the greatness of the scholar who teaches is higher than one who learns. (Tūsī, 7/70) Tabrasī and Allameh believe that Khidr (PBUH) is a Prophet. (Ṭabrasī, 6/746. Tabataba'i, 13/341 and 342) But there is a disagreement about which of these two people (Moses and Khidr) is superior. Sheikh Tūsī believes that Moses (PBUH) was superior to Khidr (PBUH) in terms of all that God had given him to guide his servants, and that Khidr's knowledge was his special knowledge. Moses (PBUH) was taught by Khidr (PBUH) only because of that knowledge. (Tūsī, 7/70) This view is consistent with the hadith of Imam Reza (AS) who considers the realm of the mission of the two Prophets to be different. (Qomi, 2/38)

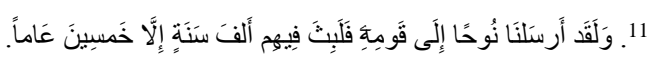


Commentators such as Seyyed Abd al-Hussein Tayyeb believe that some Prophets like Muses (PBUH) only know the appearances and others like Khidr (PBUH) know the interior (Tayyeb, 8/377) ${ }^{12}$. He considers the sentence of verse 82 of surah al-Kahf to indicate the Nubuwwat of Khidr (PBUH). (Tayyeb, 392/8) Commentators like Mughniyeh believe that one should be silent about his Nubuwwat because there is a decisive reason and there is no certain reason in the book and Tradition to prove it. (Mughniyeh, 5/145) In response to those who consider mercy as a sign of prophecy, they say: Mercy includes prophecy and general existence is not a reason for specific existence. (Mughniyeh, 5/145)

It is really debatable whether Khidr is a Prophet or not. In addition to the explicit text of the Qur'an on the last Prophet, which itself guarantees the absence of a Prophet on earth during and after the life of the Prophet Muhammad, we come across narrations in the collection of Shiite narrations that deny the existence of any Prophet after the Messenger of God. Imam Musa Kāzim (AS) says: There is no Prophet after our Prophet. (Kulaynī, 1/264) How to accept the presence of Khidr (PBUH) in the time of the Imams (AS), i.e. after the Prophet Muhammad (PBUH) as a Prophet? If we say that he was not a Prophet, how can we accept his teaching to the 'Ulu al-'Azm Prophet? If a 'Ulu al-'Azm Prophet received education from an ordinary human being, it is clear that he was superior to the Prophet in some respects. It should be noted that this story should not be compared with the story of Asif ibn Barkhiyā and Prophet Sulaymān (PBUH) because there is no discussion about education and Sulaymān (PBUH) asks Asif to do something for him. Should not the 'Ulu al-'Azm Prophet be the most learned person of his time? Some say that the Prophet should be the most knowledgeable person in his field of mission, that is, in the system of legislation. But the mission of Khidr (PBUH) was in a separate realm that had nothing to do with legislation. (Najafi Khomeini, 10/388) So where are the boundaries of the mission? How can the field of these two Prophets be separated? This way of thinking causes some people not to consider some of the commands of the Prophet (PBUH) in his field of Prophecy! And a new chapter will be opened in defiance of the Prophets and the Ahl al-Bayt. Ibn Shahr Āshūb says: It is permissible for a Prophet to be more knowledgeable that another Prophet in his time, and what Moses (PBUH) learned from Khidr is like learning from angels. (Ibn Shahr Āshūb, 1/244) In fact, this commentator assumes Khidr (PBUH) as a human who has spoken to the angels. Now, if he is human, why do we not have a similar cases in the history of the Prophets? If he is Prophet, can his degree of knowledge be as high as that of the 'Ulu al'Azm Prophet of his era, to the point where he sometimes repeatedly forced Moses to apologize? Basically, Khidr was sent to which nation, while his only addressee in the Qur'an is Moses (PBUH) and in the same story. If a Prophet has been sent with such knowledge and status above the 'Ulu al- 'Azm Prophets, why does not God mention him in detail and the type of mission and people? Ibn al-Akhshad believes that it is permissible that Khidr was not a Prophet and that he was only a pious servant to whom esoteric sciences were entrusted. (Tabrasī, 746/6) Therefore, a pious servant is busy teaching the 'Ulu al'Azm Prophet! Some say that he was a king (Țabrasī, 6/746; Tūsī, 7/70; Qomi, 2/42) which is not acceptable. In the narrations, there is no mention of the Prophet Khidr (PBUH), but even in some cases, the descriptions made of him are not compatible with his humanity. In two narrations, a Prophet with this name is mentioned, but there is no explanation as to whether the person in question is the teacher of Moses (PBUH).

\section{4-3.The Finality of Prophethood and the Prophethood and the Eternal Life of Khidr (PBUH)}

The finality of the Prophethood of Prophet Muhammad (PBUH) is explicitly stated in verse 40 of Surah al-Aḥzāb and also the narrations. Ibn Babawayh, al-Amālī, 187; Ibn Hanbal, 3/79, Kulaynī, 1/264.) so how we accept the presence of Khidr (PBUH) as a Prophet after the Prophet Muhammad (PBUH) and sometimes as the companion of Imam Mahdi (AS) during the time of occultation? (Ibn Babawayh, "Kamal al-Din wa Tamam al-Ni'mah", v. 2, p 390) while Sheikh Tūsī has not definitively accepted the Prophethood of Khidr (PBUH), says that if we consider Khidr (PBUH) as a Prophet with a special law, this law has become obsolete during the time of the Holy Prophet (PBUH), therefore his presence in this

12. Of course, the author considers the Prophet aware of the seen and unseen. 
era will not be in contradiction with the hadith of Imam Kāzim (AS) and other narrations. (Tūsì, AlTibyān, vol. 7, p. 70) In response to this statement, we will suffice with the words of Amir al-Mu'minin Ali (AS), who explicitly speaks about the finality of prophecy and revelation in the years before the Holy Prophet (PBUH) and said: "God sent the Holy Prophet after a while that he did not send a Prophet on His behalf and sent him after all Prophets and completed the revelation and prophecy through him." (Nahj alBalāghah, 191) With these explanations, the question arises as to how a Prophet with an obsolete Shari'ah is a Prophet when no one sees or recognizes him and considering the end of the revelation, how can one be called a Prophet when he no longer receives revelation?

\section{4-4.Khidr (PBUH) With Missions in the Developmental System}

Some scholars consider Khidr (PBUH) as a Prophet with missions in the developmental system and believe that God commands a group of angels or some human beings (like Khidr (PBUH)) to implement the developmental system. (Ṭabrasī, 6/746; Tūsī, 7/70; Qomi, 2/42) Some also implicitly accept this issue. For example, Ibn Shahr Āshūb says about the murder of a young man, "It does not matter if God killed him or ordered him to be killed." (Ibn Shahr Āshūb, 1/245) The death of a person due to maintaining the faith of his father and his mother in the future is not something that has a way in the Shari'a and is acceptable only by defining the developmental system. In some narrations, Elias (PBUH) also has responsibilities such as Khidr (PBUH) (Tayyeb, 377/8), but in the Qur'an, there is no example of human beings with a mission in the developmental system. Moreover, in the Qur'an, such a person is not defined for them, but they have been sent only to guide people with the usual duties of prophecy: "And lo! Elias was of those sent (to warn), When he said unto his folk: Will ye not ward off (evil)?" (Sāffăt: $123-124)^{13}$

The men of God in the developmental system are clearly angels and if we consider Khidr (PBUH) with duties in the developmental system, we have made an exception without reason that is not compatible with the definition of Prophets and their mission in the world system; a Prophet who does not invite people to truth and guidance. He is not even among the people or they do not know him, a Prophet who is not in line with the philosophy of the resurrection of the Prophets, that is, guiding the misguided, and only those who are guided to the highest and sincere can visit him. In the Qur'an, the philosophy of sending the prophets has been mentioned as the recitation of the holy verses and the teaching wisdom and purification of what the people did not know: "' (Baqarah: 151) $)^{14}$

Such prophecy mentioned for Khidr is in unresolved conflict with the holy Qur'an.

\section{Investigating a Possibility}

Given the unresolved suspicions, there is another possibility. It is obvious that Prophets, including Moses, received revelation from angels. Now, if the companion of Moses (PBUH) is an angel of the divine angels, what will happen? Will not all questions and doubts be resolved? What evidences can be obtained from the Qur'an and hadiths in this regard? Are there any similarities between him and the angels? In the Qur'an and even in the narrations, no human being, whether a Prophet or a non-Prophet, has duties in the realm of the system of creation, and even in spite of the unseen knowledge that God has given them, they have not been allowed to act on it.

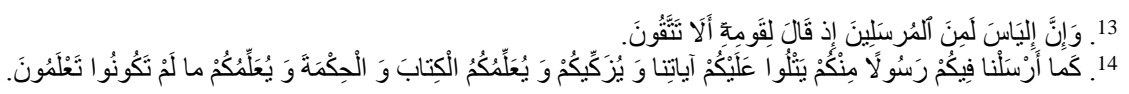




\section{5-1. Similarities Between Khidr and Angels}

According to some commentators, it was observed that the actions of Khidr (PBUH) are justified if his responsibility is in the field of the developmental system. On the other hand, according to the Qur'an, it is the basis of the duties of the angels in the developmental system and includes everything from planning to taking souls. (Al-Nāzi'āt: 1 to 5; Al-Ṣāffāt: 1-3; Al-Dhāriyāt: 1-4; Al-Mursalāt) According to verses 1 to 4 of surah Dhâriyāt, all the measures of the universe are the duties of angels. Another function of angels in the Qur'an is to mediate divine teaching for Prophets and human beings. Like Hārūt and Mārūt who were responsible for educating human beings. (Al-Baqarah: 102). They were divine angels, who were assigned to teach magic to humans at the disposal of magic of witches among them. What is the similarity of Khidr in Surah al-Kahf with the angels and their duties in the Qur'an?

\subsubsection{Equality of Nature and Duties of Khidr and Angels}

Khidr (PBUH) is introduced in the Qur'an at the beginning of the story as follows: "Then found they one of Our slaves, unto whom We had given mercy from Us" (Kahf: 65) ${ }^{15}$. In the Qur'an, we see that God frequently mentions angels as servants with good attributes. For example, in Surah Zukhruf God has mentioned the angels as servants and has said: "And they make the angels, who are the slaves of the Beneficent, females. Did they witness their creation? Their testimony will be recorded and they will be questioned." (Zukhruf: 19) ${ }^{16}$

In addition, in verse 26 of surah Anbiyā' referred to them as the Most Merciful Worshipers and has said: "And they say: The Beneficent hath taken unto Himself a son. Be He Glorified! Nay, but (those whom they call sons) are honoured slaves."

In the Qur'an, whenever a person is addressed with the word 'Abd (i.e. servant), we have a parallel to whether he is a human being or an angel, but there is no mention of this issue here, so he cannot be considered a human being and even higher we can say that Khidr behaved outside the realm of power and duties of a human being, even though he was a Prophet. More importantly, there is no compelling reason to deny his being an angel. Rather, there is a complete and uniform similarity in the description of personality between Moses' companion and the angels, which is a very strong analogy in considering the companions of Prophet Moses as an angel. On top of all this, as it turned out, knowing Prophet Khidr as a human being will create unanswered problems. However, by considering him as an angel, all questions and problems are automatically eliminated and a new chapter is opened in recognizing the interpretation and content of things and recognizing the wisdom of God Almighty in the events of the world of creation. In addition to the resemblance of Khidr's personality to the nature of angels, the similarity of Khidr's actions with the actions and duties of angels in the Qur'an is also very significant. In the Qur'an tasks such as taking the lives: "those whom the angels take (in death)" (Nisā': $97^{18}$; Nahl: $28^{19}$; Muhammad: $27^{20}$ ) and "By those who drag forth to destruction, By the meteors rushing." (Nāzi'āt: 1-2) ${ }^{21}$

And planning for affairs (And those who govern the event) (Nāzi'āt: 5$)^{22}$ has been entrusted to the angels. This is while at the end of the story of Surah al-Kahf, Prophet Khidr says: "and I did it not upon my own command" (Kahf: 82).

And this is a repetition of the words of the angels in another verse of the Qur'an which says: "We (angels) come not down save by commandment of thy Lord" (Maryam: 64)

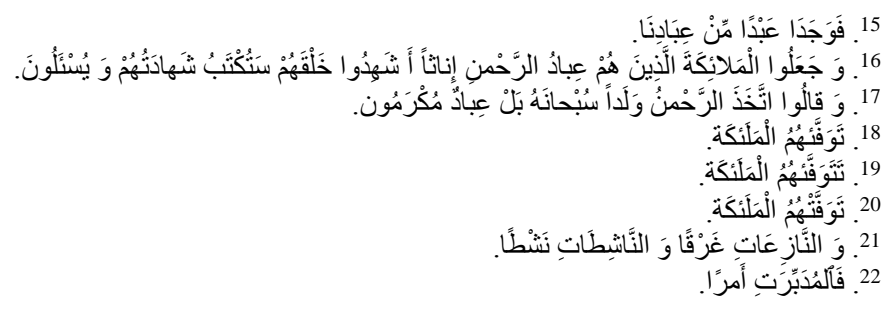

Explaining the Quiddity of Prophet Khidr (PBUH) with the Focus on Interpretive Analysis of Verses 60 to 82 of Surah Al-Kahf and Removing Doubts About It 
Other similarities between Khidr and the angels is their divine teaching is for the Prophets. All the Prophets have been taught by God through the divine angels and with them, especially Gabriel. The teaching of the Holy Prophet (PBUH) at the beginning of the revelation by Gabriel ('Alaq: 1) and also accompanying him on the night of Mi'rāj to be aware of the secrets and attribute all these cases to God is one of the proofs of the word (Isrā': 1; Najm, 1-18) the same similarity of interpretations used for angels and Khidr (PBUH) and on the other hand similar behaviors, and the subsequent silence of Prophet Moses and those around Moses and Khidr during the execution of Khidr's mission and not being exposed to him, is very significant. And all of them are stories of Khidr belonging to many angels sent by God who are adorned with divine knowledge and mercy. With this attitude, we consider the story of Moses and Khidr once again. At the beginning of the story, Moses (PBUH) is not alone and a companion accompanies him, but after the presence of Khidr (PBUH), there is no trace of this companion in the Qur'an, and of course there is no mention of separation between the two in the Qur'an. Some believe that Moses' companion was also with these two people. (Qomi, 2:39) Some say that apparently he was separated from Moses (PBUH). But there may be another truth. So that, these events took place in the inner world and the world of the revelation on Moses, and Moses (PBUH) was receiving revelation and being taught by God through an angel of the divine angels. Therefore, neither that companion nor other people who can witness the story of Moses and Khidr, do not see the events, are not surprised, and do not hear any questions or objections from them. This teaching has been done in order to increase the spiritual capacity of Prophet Moses to understand the truths of the universe and his divine training. In fact, God does not want to oblige Moses with these teachings to base the legislation of his religion on these teachings, but merely to show the interpretation and wisdom of events, however unpleasant, to his Prophet so that he may be as objective as possible aware of the truth of the verse, "but it may happen that ye hate a thing which is good for you, and it may happen that ye love a thing which is bad for you" (Baqarah: 216) ${ }^{23}$. This teaching of God was like the story of Abraham (PBUH) and observing the quality of the resurrection of the dead, which revealed truths to reassure him.

\subsubsection{Representing Angels in the Qur'an as Human Beings}

Another similarity is in the representation of angels as human beings in various stories in the Qur'an and the story of Moses and Khidr. The Holy Qur'an has repeatedly mentioned the representation of angels in human form in some cases. This allegory was intended to convey a message from God to the Prophets and saints, all of which are similar in not knowing the nature of angels at the beginning of the story. One of these is the meeting of the angels with Abraham and his wife. In this meeting, at first, Ibrahim (PBUH) does not know them. Next, the angels introduce themselves and promise the birth of Isaac to Ibrahim (PBUH) and his wife. (Hūd: 69-73; Al-Hijr: 51-55; Al-Dhāriyāt: 24-30) In another story, the same angels visit Lüt. Lüt (PBUH) does not know them and tries to defend his guests. The angels introduce themselves and announce the imminence of the promise of doom (Hūd: 77 to 81; Al-Hijr: 61 to 74; Al-Ankabūt: 33 and 34). Another example is in the story of Prophet David and the rise of two adversaries from the altar who were two divine angels and were presented as humans to teach him (p. 2125). In another story, an angel visits Mary (PBUH). Maryam (AS) also considers him human at first. The angel Introduced himself an angel sent by God, he told her soon she will have a child. (Maryam: 16-21) The remarkable point is that the angels were not recognized by Ibrahim (PBUH), Lūt (PBUH) and Maryam (AS)! Therefore, we can say that the angels revealed on Prophet Moses also carry a message, news and teaching from God for this great Prophet, and at the time of teaching Moses, he was not aware of his being an angel and therefore frequently asked questions and protested him. If he had known from the beginning that he was an angel, a bearer of revelation, and divine teaching, he would certainly not to object or even ask question. And the silence of Moses after expressing the interpretations of the events by Khidr or the same angel that attributed all matters to God, is the proof of our words. What we have noticed is the similarity in the field of duties of Prophet Khidr with the duties of angels in the Qur'an. It can be said that they, like Hārūt and Mārūt, have tried to solve a bigger problem by doing what seems

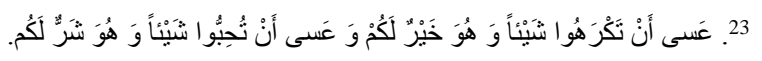


wrong at first glance; they took the young man's life like the angel of death and, like Michael, saved the property of two orphans. All of this was done to convey a message from God to Moses, like Gabriel.

\subsubsection{Mercy and Knowledge Given to Khidr (PBUH)}

Another reason for Khidr being an angel is the interpretation that God has given of him in the

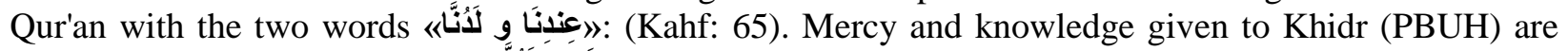

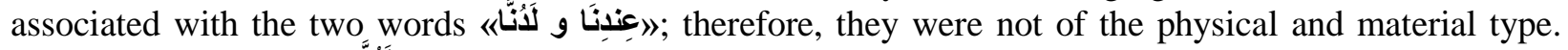

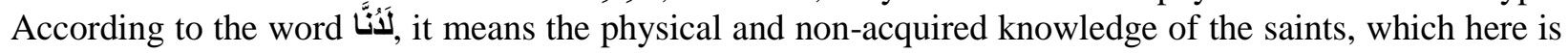
the science of Ta'wīl. (Tabataba'i, 13/341 and 342; Sadeghi Tehrani, 18/146). The knowledge given by God is not only for the Prophets, but according to verse 32 of Surah Al-Baqarah, the angels also have knowledge from God. Khidr (PBUH) does not perform these deeds based on his special knowledge, but according to the command of God, he is obliged to do things (Al-Kahf / 82).

\section{Conclusion}

The special creation of angels has separated their nature from humans. The special nature of Prophet Khidr (PBUH) is as close to angels as he is far from humans. If we consider Khidr one of the angels, most of the doubts about these verses will be removed. The fundamental differences in identity and deeds of Khidr with human beings in general and the Prophets in particular make it unlikely that Moses' companions were human. This is in addition to the insolvable questions and similarities that are mentioned following Khidr being a human. On the other hand, the identity and practical similarities between Khidr and the angels in the Qur'an cause us to consider the possibility that he is an angel, and with this idea, many doubts and questions have been resolved, and the philosophy and wisdom of this companionship and its effects on Moses' life, and its mention in the Qur'an becomes even more obvious to the Messenger of God. With this theory, the meaning of many narrations becomes clear, because Prophet Khidr, like other angels, is present in all ages and goes to visit the Imams and Sahib al-Zaman, because his life, like other angels, will continue until the blowing of trumpets, and the fountain of youth is not necessary to justify his presence. In fact, Prophet Khidr, like other angels, has planned and taken a life. Like Hārüt and Mārüt, he seems to have done something wrong to actually solve a bigger problem; he took the young man's life like the angel of death and, like Michael, saved the property of two orphans. All this has been done so that, like Gabriel, he would be a teacher and messenger from God to Prophet Moses to recite dhikr on him. He has come to teach us that there is God's mercy behind all things, and if we are patient, their interpretation will become clear to us.

\section{Bibliography}

Nahj al-Balaghah, editor: Subhī Saleh, Qom, Hijrat, first edition: 1414 AH.

Ibn Bābiwayh, Mohammad Ibn Ali, Al-'Amālī, Tehran, Ketabchi, sixth edition, 1997.

, 'Ilal al-Sharā", Qom, Davari Bookstore, First Edition, 2006.

, Man Lā Yahduruh al-Faqīh, Edited by: Ali Akbar Ghaffari, Qom, Islamic Publications Office affiliated with the Society of Teachers of the Seminary of Qom, second edition, $1413 \mathrm{AH}$.

Ibn Hanbal, Abu Abdullah Ahmad ibn Muhammad, Musnad of Imam Ahmad ibn Hanbal, Researcher: Shoaib Al-'Arnout and Adel Murash, Beirut, Al-Risālah Institute, first edition, 1421 AH - 2001 AD.

Ibn Shahr Āshūb Mazandarani, Mohammad Ibn Ali, Mutashābih al-Qur'an wa Mukhtalifuh, Qom, Bidar Publications, first edition, $1410 \mathrm{AH}$. 
Abu al-Futuh al-Razi, Husayn ibn Ali, Rawd al-Janān wa Rūh al-Jinān fì Tafsīr al-Qur'an, Editor: Dr. Mohammad Jafar Yahaqi and Dr. Mohammad Mehdi Naseh, Mashhad, Astan-e Qods-e Radawi Research Foundation, 1408 AH.

Bahrānī, Sayed Hāshim, Al-Burhān fì Tafsīr Al-Qur'an, Editor: Qism al-Dirāsāt al-Islāmīya al-Mu'assisat al-Bi'tha, Tehran, Bi'tha Institute, first edition, $1416 \mathrm{AH}$.

Balkhī, Muqātil Ibn Sulaymān, The Commentary of Muqātil ibn Sulaymān, Editor: Abdullah Mahmoud Shahāta, Beirut, Dar 'Thyā' al-Turāth, first edition, 1423 AH.

Hosseini Shah Abdul 'Azīmī, Hossein Ibn Ahmad, Tafsīr Ithnā 'Asharī, Tehran, Mīqāt Publications, first edition, 1984.

Rāghīb Isfahānī, Hussein Ibn Mohammad, Al-Mufradāt fì Gharīb al-Qur'an, Editor: Safwān 'Adnān Dāvūdī, Damascus and Beirut, Dar al-'Ilm and Dar al-Shāmīya, First Edition, 1412 AH.

Suyūtī, Jalal al-Din, Al-Durr al-Manthūr fı̀ Tafsīr al-Ma'thūr, Qom, Library of Ayatollah Marashī Najafī, $\mathrm{Np}, 1404 \mathrm{AH}$.

Shubbar, Sayed Abdullah, Tafsīr al-Qur'an al-Karim (Shubbar), Beirut, Dar al-Balāghah for printing and publishing, first edition, $1412 \mathrm{AH}$.

Sādeghī Tehrani, Mohammad, Al-Furqān fì Tafsìr al-Qur'an bil-Qur'an, Qom, Islamic Culture Publications, second edition, 1986.

Tabātabā'ì, Sayed Muhammad Hussein, Al-Mīzān fì Tafsìr al-Qur'an, Qom, Islamic Publications Office of the Society of Teachers of the Seminary of Qom, fifth edition, 1417 AH.

Tabrisī, Fadl Ibn Hassan, Majma' al-Bayān fì Tafsīr al-Qur'an, Tehran, Nasser Khosrow Publications, third edition, 1993.

Tabarī Āmulī Saghīr, Muhammad ibn Jarīr ibn Rostam, Dalā'il al-Imāmah, Editor: Qism al-Dirāsāt alIslāmīyya Mu'assisat al-Bi'tha, Qom, Bi'that Foundation, first edition, $1413 \mathrm{AH}$.

Tūsī, Muhammad ibn al-Hassan, Al-Tibyān fì Tafsīr al-Qur'an, Edited by: Ahmad Qasīr Āmilī, Beirut, Dar 'Ihyā' al-Turāth al-Arabi, Np.

Tayyib, Sayed Abd al-Hussein, Atyab al-Bayān fì Tafsīr al-Qur'an, Tehran, Islam Publications, second edition, 1999.

'Arūsī Huwayzī, Abd Ali ibn Jum'a, Tafsīr Nūr al-Thaqalain, Editor: Sayed Hashem Rasooli Mahallati, Qom, Ismailian Publications, Fourth Edition, 1415 AH.

'Azīmah, Saleh, Semantics of Quranic Words, Translator: Seyed Hossein Seyyedi, Mashhad, Behnashr Publishing Company, First Edition, 2001.

'Ayāsh̄̄, Mohammad Ibn Masoud, Kitāb al-Tafsīr, Edited by Seyed Hashem Rasooli Mahallati, Tehran, Elmieh Printing House, first edition, 1380 AH.

Fakhruddīn Rāzī, Abu Abdullah Muhammad ibn Umar, Mafātīh al-Ghayb, Beirut, Dar 'Ihyā' al-Turāth alArabi, third edition, $1420 \mathrm{AH}$.

Fooladvand, Mohammad Mahdi, Translation of the Qur'an, Tehran, Dar al-Qur'an al-Karim (Office of Islamic History and Knowledge), first edition, $1415 \mathrm{AH}$.

Fayd Kāshān̄i, Mullah Mohsen, Tafsìr al-Sāfì, Editor: Hussein A'lamī, Qom, Islamic Propagation Office Publishing Center, first edition, $1418 \mathrm{AH}$. 
Qummī, Ali ibn Ibrahim, Tafsīr al-Qummī, Corrected by: Tayyib Mousavi Jazā'irī, Qom, Dar al-Kitāb, Qom, third edition, $1404 \mathrm{AH}$.

Karājak̄i, Muhammad ibn Ali, Kanz al-Fawā'id, Editor: Abdullah Ni'ma, Qom, Dar al-Zhakhā'ir, first edition, $1410 \mathrm{AH}$.

Kulain̄ī, Mohammad ibn Ya'qūb, Al-Kāfĭ, Editor: Ali Akbar Ghaffārī and Mohammad Ākhundī, Tehran, Dar al-Kutub al-Islāmīyah, Fourth Edition, 1407 AH.

Majlisī, Mohammad Bāqir, History of the Prophets (AS), Qom, Sarvar Publications, Np, 1996.

$\mathrm{AH}$.

Mughnīyeh, Mohammad Jawad, Tafsīr al-Kāshif, Tehran, Dar al-Kutub al-Islāmīyah, first edition, 1424 AH.

Mufīd, Muhammad ibn Muhammad, Al-Ikhtisās, Corrected by: Ali Akbar Ghaffārī and Mahmoud Muharramī Zarandī, Qom, Al-Mu'tamar al-Ālamī li-'Alfīyat al-Sheikh Al-Mufīd, first edition, 1413 AH.

Makarem Shirazi, Nasser, The Commentary of Nemooneh, Tehran, Dar al-Kutub al-Islāmīyah, first Edition, 1995.

Mirza Khosravani, Ali Reza, The Commentary of Khosravi, Editor: Mohammad Baqer Behboodi, Tehran, Islamiyah Publications, first Edition, $1390 \mathrm{AH}$.

Najafi Khomeini, Mohammad Javad, The Commentary of Asan, Tehran, Islamiyah Publications, first Edition, $1398 \mathrm{AH}$.

\section{Copyrights}

Copyright for this article is retained by the author(s), with first publication rights granted to the journal.

This is an open-access article distributed under the terms and conditions of the Creative Commons Attribution license (http://creativecommons.org/licenses/by/4.0/). 